Meta

Journal des traducteurs

Translators' Journal

\title{
Literary Translation: The experience of translating China Achebe's Arrow of God into French
}

\section{Irène Assiba d'Almeida}

Volume 27, numéro 3, septembre 1982

URI : https://id.erudit.org/iderudit/001876ar

DOI : https://doi.org/10.7202/001876ar

Aller au sommaire du numéro

Éditeur(s)

Les Presses de l'Université de Montréal

ISSN

0026-0452 (imprimé)

1492-1421 (numérique)

Découvrir la revue

Citer cet article

d'Almeida, I. (1982). Literary Translation: The experience of translating China Achebe's Arrow of God into French. Meta, 27(3), 286-294.

https://doi.org/10.7202/001876ar d'utilisation que vous pouvez consulter en ligne. 


\section{LITERARY TRANSLATION : THE EXPERIENCE OF TRANSLATING CHINUA ACHEBE'S ARROW OF GOD INTO FRENCH}

IrÈne Assiba D'Almeida

It is not our intention in this article to once again go back to the vexed question of whether or not translation is an art or a science nor is it to find out whether the famous Italian idiom "traddutore, traditore" is true or false. Vinay and Darbelnet have successfully answered the first question when they contended that "La traduction devient un art une fois qu'on en a assimile les techniques" ". As for the shortcomings which are often inherent in translation Goethe had this pertinent remark to make as early as 1827: "Say what one will of the inadequacy of translation it remains one of the most important and worthiest concerns in the totality of world affairs" 2 .

Our study will focus attention on the most salient problems posed when translating an African novel, namely Achebe's Arrow of God into French.

If we may start with general considerations it might be relevant to point out that translation has, in the course of time, been given a number of various definitions. The following one which is succint but to the point seems to give in a simple way a fair account of what the whole exercise is taken to be. It is indeed "the replacement of textual material in one language (source language) by equivalent textual material in another language (Target language)" ${ }^{3}$. On the other hand if translation laws could be drawn up one would agree that:

1. Translation should give a complete transcript of the ideas of the original work.

2. That the style and manner of writing should be of the same character with that of the original.

3. That the Translation should have all the ease of original composition ${ }^{4}$.

In other words the translator's task is not only to convey the writer's ideas but also to render his or her style in such a way as to make the translation read naturally to a native speaker of the target language which in this case is French while the source language is English.

1. J.P. Vinay and J. Darbelnet (1958): Stylistique Comparée du Français et de l'Anglais, Didier, Paris, p. 24.

2. Goethe, to Carlyle, $20^{\text {th }}$ July 1827 , quoted by L. Bonnerot, L. Lecocq. J. Ruer, H. Appiah and H. Kerst, in Chemins de la Traduction, Domaine Anglais, Didier, Paris, p. 60.

3. J.C. Catford (1965) : A Linguistic Theory of Translation, Oxford University Press, p. 20.

4. Alexander Fraser Tyler, Lord Woodhouselee (1781): Essay on the Principles of Translation, Every man Edition, p. 8-9. 
The first difficulty the translator is confronted to is the very differences which exist between French and English. Each language is full of its own proprieties and carries its own peculiar meaning and, in lexical meanings words acquire various overtones and associations that are not shared by the nearest corresponding words in another language. The English and the French to not apprehend the world in the same manner and as a result marked differences exist not only linguistically but also culturally betwen the two languages. Indeed culture and language are closely interrelated because languages do not operate in isolation but within and as part of cultures and cultures differ from each other in different ways. It is through language that culture is expressed and, on the otherland, a culture nourrishes the language that carries it and that is why new cultural experiences often make it necessary to enlarge the resources of language. Linguistically, English and French differ in many ways. For instance, although English is lexically richer, it is a much more concise language than French which is rather diffuse. Also, English is basically a concrete language whereas French is more abstract. English is synthetic whereas French is analytic. Syntactically, English constructions can often be exactly matched in French but it is not always so. Since no writer writes in a haphazard way - there is always a conscious choice of words, of structural devices, of stylistic subtleties, of figures of speech - a thorough stylistic analysis of a text is an indispensable starting point when a translation is to be carried out.

Once the linguistic and cultural differenciations are identified and devices are found to tackle them, the translator faces another problem, that of drawing aside to let the writer express himself through him or her. In other words the translator has to impersonate the writer. That is what Batteux meant when he said: "Le traducteur n'est maître de rien; il est obligé de suivre partout son auteur, de se plier à toutes ces variations avec une souplesse infinie" 5 . Impersonation is an important exercise because by going through it the translator has a better insight into the writer's turn of thought and expression and as a result stands a lesser chance of altering or destroying the substance to be translated or of presenting him or her (the writer) through a distorted medium. When it is an African person who is translating an African writer, impersonation is somewhat easier and more effective because the African person is more familiar with the cultural background in which the actions occur and in which the characters are set. Religious rituals, festivals, customs and even day-to-day occurrences are seen from within because they are part of a shared experience. For instance in chapter 12 Oduche and Ojiugo his half-sister are having a fight at the stream: a crowd gathers in no time, onlookers take sides, women start abusing each other. The moment the children go back home their respective mothers who are cowives give the incident overblown proportions and Ezeulu has to intervene to restore the disrupted peace within the compound. This episode which is so very vividly described is typical of what happens in many poligamous homes and an African translator can better visualize it, understand it and perhaps as a result render it in a more accurate manner.

5. Batteux, De la Construction Oratoire, quoted by Bonnerot and others, op. cir. p. 137. 
The next problem stems from the fact that both Achebe and his translators are using languages which do not strictly belong to them in the sense that they are not native speakers of these languages. Achebe here is using the English language to express an African experience. He has said in inequivocal terms that "the African writer [...] should aim at fashioning out an English which is at once universal and able to carry his peculiar experience" 6 . And he has also said - and proved it too in a masterly way -.

[...] I feel that the English language will be able to carry the weight of my African experience. But it will have to be a new English, still in full communion with its ancestral home but altered to suit its new African surroundings ${ }^{7}$.

Because he is a talented writer Achebe has succeeded in twisting effectively the English language so as to suit his own purpose. A problem of translation arises here from the fact that somehow, the French language does not as easily yield itself to being so twisted and this in itself constitutes a serious challenge. Let us take an example extracted from one of Nwaka's speeches.

[...] The white man is Ezeulu's friend and has sent for him. What is so strange about that? He did not send for me. He did not send for Udeozo; he did not send for the priest of Uru; he did not send for the priest of Udo nor did he ask the priest of Ogwugwu to come and see him. He has asked Ezeulu. Why? Because they are friends. Or does Ezeulu think that their friendship should stop short of entering each other's houses? Does he want the white man to be his friend only by the word of mouth? Did not our elders tell us that as soon as we shake hands with a leper he will want an embrace? It seems to me that Ezeulu has shaken hands with a man of "white body". This brought low murmurs of applause and even some laughter. Like many potent things from which people shrink in fear leprosy is nearly always called by its more polite and appeasing name - white body. The applause and laughter were mingled with the salutation. Owner of words to Nwaka. He waited for the laughter to die down and said: "If laughter presses you, you can laugh; as for me, it does not press me". Ezeulu sat in the same way as he had sat when he ended his speech ${ }^{8}$.

And thus goes the translation:

L'homme blanc est l'ami d'Ezeulu et lui a demandé de venir le voir. Y a-t-il quelque chose d'étrange à cela? Il ne m'a pas invité. Il n'a pas invité Udeozo; il n'a pas invité le prêtre d'Idemili; il n'a pas invité le prêtre d'Eru; il n'a pas invité le prêtre d'Odo ni celui d'Ogwugwu à aller le voir. Il a invité Ezeulu, pourquoi? Parce qu'ils sont amis. Ou bien Ezeulu croit-il que leur amitié devrait s'arrêter au portail de leurs maisons respectives? Veut-il que l'homme blanc ne soit son ami qu'en paroles? Nos anciens ne nous disent-ils pas que dès que l'on serre la main à un lépreux il veut qu'on l'embrasse! Il me semble que Ezeulu a serré la main à un «corps blanc... » A ces mots, il y eut des murmures d'approbation et même quelques rires. Comme la plupart des choses enveloppées de puissance devant lesquels les hommes reculent de frayeur la lèpre était toujours appelée par un autre nom, plus courtois et plus tranquillisant: le corps blanc. Au milieu des murmures d'approbation et des rires, on entendait des mots d'admiration à l'endroit de Nwaka: «Tu as de la verve» lui disait-on. Il attendit que le bruit s'éteigne et dit : «Si vous

6. C. Achebe (1965): "The African writer and the English Language", Transition, Accra, vol. 4, No. 8, reproduced in Morning Yet on Creation Day, Heinemann, 1975, p. 62.

7. Ibidem, p. 62.

8. C. Achebe (1964): Arrow of God, Heinemann, second edition 1974, p. 143-4. (N.B. All subsequent quotations are made from this edition). 
avez envie de rire, alors riez; quant à moi, je n'en ai guère envie». Ezeulu resta assis dans la même position, celle-la même qu'il avait prise à la fin de son discours ${ }^{9}$.

We have earlier on made a point about the interraction of language and culture. Here the problem is even more complex because within the same source language two cultures are involved : the English culture since English is the linguistic medium of the novel, and the African culture seen through an Ibo worldview. To solve this problem Achebe has "devised an African vernacular style which simulates the idiom of Ibo, his native tongue" 10 . That is why apart from the choice of words and the specific way he arranges them Achebe makes a profuse use of proverbs, metaphors and similes which describe the cultural atmosphere in which actions unfold, the cultural milieu in which characters evolve. Two examples will illustrate this :

I have my own way and I shall follow it. I can see things where other men are blind. That is why I am known and at the same time I am unknowable. You are my friend and you know whether I am a thief or a murderer or an honest man. But you cannot know the thing which beats the drum to which Ezeulu dances. I can see tomorrow; that is why I can tell Umuaro: come out from this because there is death there or do this because there is profit in it. If they listen to me, o-o; if they refuse to listen, $0-0$.

Arrow of God, p. 132.

J'ai ma propre voie et je la suivrai. Je peux voir des choses quand les autres sont aveugles. C'est pour cela que je suis à la fois le Connaissable et l'Inconnaissable. $\mathrm{Tu}$ es mon ami et tu sais si je suis un voleur un assassin ou un homme honnête. Mais tu ne peux pas connaitre la chose qui bat le tam-tam au son duquel Ezeulu danse. Je peux voir l'avenir. C'est pourquoi je peux dire à Unuaro: "Sors de ce mauvais pas, car il y a la mort au bout, ou bien fais cela, car tu en tireras du profit'. S'ils m'écoutent $\mathrm{O}$-ho-o, s'ils refusent de m'écouter, o-ho-o »

La Flèche de Dieu, p. 178

The last sentence here could have been translated by "s'ils m'écoutent tant mieux, s'ils refusent de m'écouter, tant pis" but the African idiom would have been lost. The following example shows the use of proverbs :

"What I say is this" continued Nwaka, "a man who brings ant-ridden faggot into this hut should expect the visit of lizards. But if Ezeulu is now telling us that he is tired of the white man's friendship our advice to him should be ; you tied the knot, you should also know how to undo it. You passed shit that is smelling, you should carry it away. Fortunately the evil charm brought in at the end of the pole is not too difficult to take outside again.

Arrow of God, p. 144 - Je dis, continua Nwaka, qu'un homme qui amène des fagots infestés de fourmis dans sa case doit s'attendre à la visite des lézards. Mais si Ezeulu est en train de

9. C. Achebe, Arrow of God, translated into French under the title La Flèche de Dieu by Irene Assiba d'Almeida and Olga Mahougbé Simpson, Présence Africaine, 1978, p. 192-3 (N.B. All subsequent quotations are made from this edition).

10. Bernth Lindfors (1968): "The palm oil with which Achebe's words are eaten", African Literature Today, No. 1, p. 4 (For the problems of language in African writing see also, Gerald Moore (1964): "English Words, African Lives", Présence Africaine, 26, 54, 2nd Quarterly, p. 90-101; B.I. Chukwukere (1969): "The Problem of Language in African creative writing" African Literature Today, No. 3, p. 15-26; Ezekiel Mphahlele (1964): "The Language of African Literature" Harvard Educational Review, vol. 32, 12, spring, p. 298-305: G. Griffiths, "Language and Fiction in the Novels of Chinua Achebe", African Literature Today, 5, p. 88105 , and M. Kane (1966): "L'écrivain africain et son public", Présence Africaine, 58, p. 8-31. 
nous dire qu'il est fatigué de l'amitié que lui porte l'homme blanc, alors nous lui donnerons un conseil : « $\mathrm{Tu}$ as fait un noud, tu devrais savoir le dénouer. $\mathrm{Tu}$ as fait des selles nauséabondes, tu devrais pouvoir les ramasser". Heureusement, il n'est pas difficile de faire ressortir le mauvais sort que l'on a fait entrer au bout d'une perche.

La Flèche de Dieu, p. 193

Since, as he put it himself "proverbs are the palmoil with which words are eaten" Achebe makes use of them to explain, to illustrate speech. Sometimes however, proverbs are used in an esoteric manner particularly when certain rituals are being performed. They come one after the other in quick succession to create an atmosphere of awe and mystery: that is what happens when the spirit speaks :

The fly that struts around a mound of excrements wastes his time; the mound will always be greater than the fly. The thing that beats the drum for ngwesi is inside the ground. Darkness is so great that it gives horns to a dog. He who builds a homestead before another can boast more broken pots. It is ofo that gives rainwater power to cut dry earth. The man who walks ahead of his fellows spots spirits on the way. Bat said that he knew his ugliness and chose to fly by night [...]

Arrow of God, p. 225-6

These potent words can only be rendered in the same esoteric manner in French :

La mouche qui se pavane sur un tas d'excréments perd son temps car le tas sera toujours plus grand que la mouche. La chose qui bat le tam-tam pour ngwesi est à l'intérieur du sol. L'obscurité est si dense qu'elle donne des cornes à un chien. Celui qui construit sa maison avant un autre peut se vanter d'avoir plus de canaris brisés. C'est l'ofo qui donne à la pluie la puissance de couper la terre desséchée. L'homme qui marche devant ses compagnons repère les esprits sur son chemin. La chauve-souris dit qu'elle sait combien elle est laide, c'est pourquoi elle a choisi de voler la nuit $[\ldots]$

La Flèche de Dieu, p. 294

Achebe uses many Ibo proverbs and he also uses quite a number of Ibo words but he does so in a self-explanatory way because he cleverly explains them in the course of the narrative. For instance during the covering-up sacrifice performed for Obika's wife the medicine-man says :

"Give me the omu" Edogo passed the tender palm leaves to him [...] "Let me have ego-nano". She untied a bunch of cowries from a corner of her cloth and gave them to him.

Arrow of God, p. 119

We thus know that the omu means tender palm leaves and that ego-nano represents a certain number of cowries. In such cases the translator encounters no difficulty :

- Donne moi l'omu. Edogo lui passa les jeunes feuilles de palmier [...]

- Puis-je avoir l'ego-nano? Elle défit le bout de son pagne et lui donna une poignée cauris.

La Flèche de Dieu, p. 160

Sometimes the explanation of the Ibo words is more direct, and the translation also is more direct:

Umuago celebrated their Mgba Agbogho or the wrestling of the Maidens [...] Together the six villages held the quiet retreat called Oso Nwanadi to placate 
the resentful spirits of kinsmen killed in war or in other ways made to suffer death in the cause of Umuaro.

Arrow of God, p. 193

Les habitants d'Umuagu célébraient leur $M g b a$ Agbogho ou Lutte des vierges [...] Les six villages observaient une retraite silencieuse appelée Oso $N$ wanadi pour apaiser les esprits irrités de leurs frères tués au cours d'une guerre ou qui, en d'autres circonstances, étaient morts pour la cause d'Umuaro.

La Flèche de Dieu, p. 254

However, quite a number of Ibo words are not readily understandable. Perhaps a glossary would have been an asset but Achebe himself did not provide the reader with one in the original. It may have been a deliberate choice to kindle the reader's curiosity and thus impel him or her to find out more about the cultural background of the novel.

Some expressions or sayings are clearly Ibo expressions or saying translated into English. For instance to express Obika's fears when the wonders whether Edogo, his wife-to-be is still a virgin, Achebe says: "When he took his wife to his hut after the sacrifice, would he find her at home - as the saying was or [...]" p. 118. A woman quarelling with another one threatens : "I shall beat okro seeds out of your mouth" p. 128, and the other retorts "Go and eat shit" p. 128, an expression which is later on repeated when Obika shouts his anger at the white man's messenger p. 138. These Ibo sayings would not have been expressed in the same way in other African languages. For instance in Fon which happens to be the translators' language a virgin girl is said to be "on the hand" and when you want to beat somebody to death you do not beat okro seeds out of his mouth. You beat someone until he is lost to himself; in other words, after the beating he should no longer know where he is or who he is. As for eating shit the expression exists in Fon but is attributed to a person who is cheeky, rude and shows disrespect to others particularly to elders. The best thing to do here was to just leave the expressions as they were and translate them litterally: "Quand il prendrait sa femme dans sa case après le sacrifice, la trouverait-il "à la maison" comme on dit, ou [...]" p. 159, or "Je te battrai à te faire sortir des graines de gombo de la bouche" p. 172 etc.

Also, a few English words are distorted by the indigenes who cannot pronounce them properly : Wintabota for Winterboltem, Jekopu for Jacob, Johnu for John. These words word left as they are in the French version. Some others were modified like "gorment" for government became "gouvêment" and "gorment Heel" became "la Colinou du gouvêment". If a play on words were intended here it has unfortunately been lost.

Sometimes one comes across some problem-words like doctor medicineman, herbalist which all represent the same reality, that of the "dibia", a word that Achebe does use in a few instances. In French, "docteur" is unsuitable, "rebouteux" is derogatory, "herboriste" is inappropriate. All these words were translated by "guérisseur" a word which is increasingly used in French speaking West Africa in this context.

Perhaps one of the most teasing problems was to translate the passages which the writer elected to render in Pidgin English. After much deliberation 
we have chosen to invent a kind of French gibberish as it were, and here is the result of such an undertaking:

The two policemen conferred in the white man's tongue to the great admiration of the villagers. "Sometine na dat two porson we cross for road" said the corporal. "Sometine na dem" said his companion. "But we no go return back jus like dat. All dis waka wey we waka come here no fit go for nating". The Corporal thought about it. The other continued: "Sometine na lie dem de lie. I no wan make dem put trouble for we head.

Arrow of God, p. 153-4

\section{The French version is :}

Les deux policiers se consultèrent dans la langue de l'homme blanc, à la grande admiration des villageois.

- C'est pê-ête les deux hommes-là nous rencontrer sur la route, dit le caporal.

- Pê-ête c'est eux, répondit son compagnon. Mais nous pas retourner comme ça.

Tout cette marche nous marcher! Ça peut pas ête pour rien. Le caporal réfléchit.

L'autre continua. - Pê-ête eux mentir. Moi veux pas eux mête palabre sur nos têtes.

La Flèche de Dieu, p. 204-5

Or again :

I use to tellam say blackman juju no be someting wey man fit take play. But when I tellam na so so laugh im de laugh. When he finish laugh he call me John and I say Massa. He say you too talk bush talk. I tellam say $\mathrm{O}-\mathrm{o}$, one day go be one day. You no see now?

Arrow of God, p. 155

And thus goes the translation:

Moi dire lui que gri-gri de l'homme noir ête quelque chose avec quoi personne y doit jouer. Mais quand moi dire lui, lui rire, rire seulement. Quand lui fini rire, lui dit "John" et moi répond "Missié" y dit moi aussi parler comme broussard. Moi dis lui! "O-o, un jour va vini... et on va voir. Ti voi maintenant?"

La Flèche de Dieu, p. 206

The solution which consists in inventing a substitute language to translate Pidgin English may be questioned by some or even condemned by others. Indeed "a pidgin is a marginal language which arises to fulfil certain restricted communication needs among people who have no common language" (emphasis mine) ${ }^{11}$. The emphasis is put on the word language because although it is looked down upon by many as being a bastardized form of English plus a few other borrowings, Pidgin English is indeed a language in its own right with its lexical and syntactic peculiarities. As far as we know and at least in West Africa there is no French Pidgin in that sense, except perhaps in Ivory Coast. This of course does not justify the fallacious assumption which would have one believe that in the former French Colonies French was spoken very well or not at all. As a matter of fact some people who, for one reason or the other did not master French did speak and still speak a kind of unorthodox French derogatorily called "Français petit-nègre". It is because this so called language seems to be the nearest one can find to Pidgin English that we have chosen to translate

11. Loreto, Todd (1974): Pidgins and Creoles, Routledge \& Kagan Paul, London and Boston, p. 1. 
it in this manner. As a result one could wonder whether the use of an invented "petit nègre" is artistically and culturally justifiable or whether the shortcomings notwithstanding this device does convey the meaning and the feeling conveyed by the writer. We may concede that perhaps technically it may not be totally appropriate. However it does convey both meaning and feeling, which is most important if we agree that: "ce qu'il faut atteindre c'est l'identité non pas seulement d'expression mais d'impression"' 12 .

However, another way of tackling the problem would have been to render the passage written in Pidgin in orthodox French and then resort to translator's notes which would explain that such passages were written in Pidgin in the original. This is often done by some European translators who are faced with the problem of translating dialects from a specific source language into a target language. How indeed is it possible to translate into French a dialogue written in Scottish English? This is indeed a problem and one can clearly see how and why it may prove desirable to resort to translator's notes in such cases.

All these problems show the vanity of wanting to evolve a system whereby translations will be made automatically. Machine translation is the aim of an age that would reduce all activities to techniques and these machines could be useful to deal with scientific translations in particular. Many attempts have been made to invent such machines and one of the most recent ones called the Weidner is a Multi-Lingual Word Processing system thus described :

Consisting of a mini-computer, an electronic typewriter and a video-display screen [...] the Weidner device has potential vocabulary of 3 million words and can translate idioms and homographs - words that are spelled the same but have different meanings. Despite its broad capabilities, the translating machine is extraordinarily simple to use. A person simply punches in the original text on a typewriter keyboard and the working translation appears immediately on the video screen. To complete the translation, the operator need only transpose a few words or phrases for grammatical accuracy or substitute some words with others that may be more appropriate. The computer's memory even has a dictionary of synonyms for this purpose. Finally a hard copy of the edited, translated text is printed on paper ${ }^{13}$

What is interesting here is that in spite of this high level of technology an operator - a human being - has to intervene for adjustements. This factor is exploited by the designers of the machine who say:

One of the major differences between the Weidner translator and other less successful devices is that this system is meant to be an aid and not a replacement for human translators. With the help of this computer device [...] a human translator should be able to handle more than four times as much work in the same amount of time ${ }^{14}$.

Translating machines will no doubt be useful in many ways but although many attempts at machine translation of literature have been made the success in this field seems very remote at present. Indeed a satisfactory literary translation is far from literal word for word translation. Technical expertise is not enough,

12. Abel Chevalley (1927): "Enquête sur la Traduction", Cahiers du Sua, No. 89, Avril, p. 263.

13. "Instant Translation", Newsweek, 13 Nov. 1978, p. 4.

14. Ibidem, p. 4. 
stylistic adjustments have to be made and it will take some time to invent a machine which will have the tremendous complexity of a human brain with all its knowledge and sense of discrimination. 